\title{
Evaluation of Image Analysis to Determine the N-Fertilizer Demand of Broccoli Plants (Brassica oleracea convar. botrytis var. italica)
}

\author{
Simone Graeff, ${ }^{1}$ Judit Pfenning, ${ }^{2}$ Wilhelm Claupein, ${ }^{1}$ and Hans-Peter Liebig ${ }^{2}$ \\ ${ }^{1}$ Institute of Crop Production and Grassland Research (340), University of Hohenheim, Fruwirthstr Straße 23, \\ D-70599 Stuttgart, Germany \\ ${ }^{2}$ Institute of Special Crop Cultivation and Crop Physiology (370), Vegetable Science, University of Hohenheim, \\ Emil-Wolff-Straße 25, D-70599 Stuttgart, Germany
}

Correspondence should be addressed to Simone Graeff, graeff@uni-hohenheim.de

Received 1 October 2007; Revised 18 March 2008; Accepted 26 May 2008

Recommended by J. Fu

\begin{abstract}
Numerous models have been developed for calculating optimum decision rules for nitrogen fertilization based on remote sensing techniques. New technologies related to digital image analysis may provide an alternative method to estimate nutrient status faster and more efficiently than current techniques. A series of field studies was conducted to determine the applicability of digital image analysis for nitrogen demand estimates in broccoli plants. Digital images were taken under constant light conditions in various wavelength ranges $(380-1300 \mathrm{~nm})$ using a digital imager. Images were processed for the parameters $a^{*}$ and $b^{*}$ in the $L^{*} a^{*} b^{*}$ color system. The image analysis showed a close correlation between the nitrogen status of broccoli plants and the parameter $b^{*}$ of the $L^{*} a^{*} b^{*}$ color system especially in the wavelength ranges $510_{780}$ and $516_{780} \mathrm{~nm}$. The relationship between nutrient concentration in leaf dry matter and the parameters $b^{*}$ was used to determine the $\mathrm{N}$ fertilizer demand within the cultivation period. Estimated $\mathrm{N}$ amounts were applied as top dressing four weeks after setting and were $100 \mathrm{~kg} \mathrm{ha}^{-1}$ lower than the standard fertilizer rate. Calculated $\mathrm{N}$ balances indicated a total uptake of applied $\mathrm{N}$ amounts in the image-based $\mathrm{N}$ treatments without considerable yield loss. Thus, digital image analysis proved to be an effective means of determining nitrogen status and adjusting fertilizer applications to preserve or enhance crop quality and yield considering sustainability.
\end{abstract}

Copyright (c) 2008 Simone Graeff et al. This is an open access article distributed under the Creative Commons Attribution License, which permits unrestricted use, distribution, and reproduction in any medium, provided the original work is properly cited.

\section{INTRODUCTION}

Accurate prediction of nutrient requirements of plants during the cultivation period is necessary for efficient fertilizer use [1]. Soil and plant analyses are currently the basic techniques to predict the nutrient status of plants in the field. However, these techniques are time-consuming, plantdestructive, and labor-intensive.

Nitrogen $(\mathrm{N})$ is the nutrient most often applied to vegetable crops as a fertilizer. One strategy for pursuing profitable yields and a high quality in vegetable production while avoiding at the same time water contamination is to only apply the amounts of $\mathrm{N}$ that will be used by the growing crop. The ability to quickly and easily monitor the nutrient demand in vegetables and to use that information to optimize $\mathrm{N}$ fertilizer inputs would directly contribute to improved crop quality and resource use efficiency.
In the last few years, low-cost digital imaging methods have become readily available easing the set-up of calibrations for the detection of different plant stresses. Imagebased methods are fast once fully developed, and they have the added advantage that images can be acquired quickly for different times to assess vegetation dynamics for monitoring purposes. In addition, images are easily archived; thus, conserving maximal data for future change analyses. Interpretation of digital images is aided by computerized processing of color parameters. Color parameters can be evaluated in different color systems. The RGB or the CIELAB color values have been mostly used to describe and analyze color images [2].

However, research in that area mainly focused on image analysis techniques for measuring and estimating vegetation cover and/or bare soil [3-6]. Digital image analysis has been used in several studies to quantify, for example, disease, 
stress, coverage, and color [5, 7-9]. These studies concluded that digital image analysis is very useful to quantify biophysical plant parameters. Images have also been used to estimate tiller densities across a field [10], to detect insect damage [11], as well as nutrient and water deficiencies [12, 13]. Up to now, a number of different stresses are detectable through images, but the pattern of specific stresses needs to be verified by controlled observations including known reference conditions within the image.

Changes in foliar color are a valuable indicator of plant nutrition and health. Leaf color can be measured with visual scales and inexpensive plant color guides that are easy to use, but not quantitatively rigorous, or by employing sophisticated instrumentation including chlorophyll meters, reflectometers, and spectrophotometers that are costly and may require special training. Reflectance data gathered with reflectometers or spectrophotometers can provide accurate and precise quantification of stress factors in plants [14-16]. Spectral indices derived from reflectance data or the single use of reflectance data have shown to be indirectly related to the nitrogen status of crops, (e.g., [17-22]). Although reflectance of a crop depends on many factors, including incident lighting and physiological condition of the crop [23], nutrient deficiencies can be detected by calibrating photographic responses within fields against responses from areas measured as nonlimiting in nutrients [12]. The assessment of the nutrient status using digital images relies on structural changes of leaf tissue. Disorientated tissue results in reduced light reflectance leading to a change of color parameters. Thus, it is desirable to capture color information of plants in color images and to analyze the images. However, most of these developed systems and calibrations have been widely tested in arable crops. Suitable calibrations for vegetables are widely missing.

Working with broccoli plants supplied with different $\mathrm{N}$ rates, we developed and tested a method of digital image analysis to determine necessary $\mathrm{N}$ fertilizer rates based on actual Nstatus. This research is intended to develop an image-processing method to assess broccoli nitrogen level based on digital images, split into several wavelength ranges by the application of different long-pass filters. The applied method converted the image into the LAB color system [24]. In 1986, the Commission Internationale d'Eclairage (CIE) updated and refined the three-dimensional Lab color system, which displays every color perceived by the human eye (CIE, 1976). Unlike RGB colors, CIE Lab colors are deviceindependent. Therefore, the visual characteristics of these colors remain consistent on monitors, printers and scanners. Colors are defined by the $L^{*}, a^{*}$, and $b^{*}$ parameters. Lightness is expressed as " $L$ " value from dark to light with 0 $=$ black and $100=$ white. The " $a$ " and " $b$ " values indicate the chromaticity coordinates. Green to red is expressed by the " $a$ " value. A more positive value represents red, while a more negative value represents green. Blue to yellow is expressed by the " $b$ " value. A more positive value represents yellow, a more negative value represents blue. $a^{*}$ and $b^{*}$ color parameters representing the reflectance of the broccoli plant across leaves were used for the discrimination of nitrogen status. The obtained data was further processed to find specific patterns in selected wavelength ranges that correspond to crop nitrogen status. To implement a wavelength analysis, the digital image was recorded in multiple wavelength ranges in the visible and near-infrared spectra and diverted into packets of narrow frequency bands to find the lowest-level approximations at different levels. The maximum coefficients were identified for interested signal bands and then compared to chemically determined nitrogen concentrations in broccoli leaves as the ground-truth nitrogen level. Thus, this study explores an innovative image-processing method to assess broccoli nitrogen status based on digital images. The paper describes the process and the validation of this pioneering research in vegetables.

\section{MATERIAL AND METHODS}

\subsection{Field experiments}

Field studies were conducted at the experimental station of horticulture $\left(697 \mathrm{~mm}\right.$ average annual precipitation; $8.8^{\circ} \mathrm{C}$ mean annual temperature), of the University of Hohenheim, Stuttgart, Germany. The first field trial consisted of two common broccoli cultivars "Parthenon" and "Marathon" and four $\mathrm{N}$ fertilization treatments consisting of 0,100 , 200 , and $400 \mathrm{~kg} \mathrm{~N} \mathrm{ha}^{-1}$. The total amount of nitrogen was split in two rates in the $400 \mathrm{~kg}$ treatment, broadcast and incorporated in all treatments by hand as KAS $\left(13.5 \% \mathrm{NH}_{4}\right.$ $\left.\mathrm{N}, 13.5 \% \mathrm{NO}_{3}-\mathrm{N}, 12 \% \mathrm{CaO}\right)$. This field trial was used to set up to derive a relationship between spectral properties of broccoli plants and nitrogen demand and to establish the necessary calibrations for the estimation of $\mathrm{N}$ fertilizer amounts.

In a second field trial the same varieties were tested under six different $\mathrm{N}$ fertilization treatments consisting of a final amount of $0,76,152,200,248$ and $304 \mathrm{~kg} \mathrm{~N} \mathrm{ha}^{-1}$. The total amount of nitrogen was split in two rates, whereof $50 \%$ was applied in the first rate at setting, broadcast and incorporated in the treatments up to $304 \mathrm{~kg} \mathrm{ha}^{-1}$ as KAS $\left(13.5 \% \mathrm{NH}_{4}-\mathrm{N}\right.$, $\left.13.5 \% \mathrm{NO}_{3}-\mathrm{N}, 12 \% \mathrm{CaO}\right)$ and in the $248 \mathrm{~kg} \mathrm{ha}^{-1}$ treatment as ENTEC26 applied at setting. The amount of the second nitrogen rate was calculated based on the $\mathrm{N}$ demand of broccoli plants derived out of the digital image analysis and thus to validate the derived calibrations.

Broccoli was planted in both trials on July 05th in 06 at a rate of 4.5 plants per $\mathrm{m}^{2}$. The trial set up was a randomized block design with four replications. Timing of $\mathrm{N}$ application was set to start of cultivation, that is, at setting and after a four-week growing period (before beginning of floret formation while period of leaf formation). Soil $\mathrm{N}_{\text {min }}$ content was determined in all plots at planting and after final harvest to calculate an $\mathrm{N}$ balance for each treatment. Broccoli plants were irrigated to ensure a nonlimiting water supply throughout the main growing period. Soil nutrient status analyses were made at the beginning of vegetation period to avoid any other nutrient deficiencies in broccoli other than nitrogen. Plant protection measures were carried out as needed to control weeds and pests. Harvest of broccoli florets started in the mid of September as soon as $50 \%$ of the plants of a plot had reached a minimum marketable head size of $\varnothing 7 \mathrm{~cm}$ or tended to show further flower development. Two 
harvests were accomplished in a four-day interval. Florets were trimmed to market specifications for broccoli and graded for diameter, weight, discoloration, and hollow stem.

\subsection{Image acquisition}

Image acquisition started two weeks after planting and was carried out once a week on the youngest fully developed leaf of each plant until final harvest of broccoli florets. Images were taken with a digital, light-sensitive (ISO 200-2400; spectral sensitivity of 250-1300 nm), high-spatial resolution (5140*5140 pixel) imager (S1 PRO, Leica, Germany). Settings of the imager were chosen according to Graeff [25]. The imager provides an entirely digital and fully automatic process to produce highly accurate digital image data. Three superimposed image tracks are acquired simultaneously by three line sensors mounted in parallel on the instrument focal plane. The imager gives as output the values of trichromatic coordinates $L^{*}, a^{*}, b^{*}$ [24]. The imager was used in conjunction with a constant light source (Reporter 21D MicroSun, $21 \mathrm{~W}$, Sachtler, Germany). The chosen light source was equipped with a $21 \mathrm{~W}$ daylight discharge bulb (Sachtler, Germany ; color temperature 5500-6000 K) which produces more light than normal $50 \mathrm{~W}$ tungsten luminaries. It has a luminous flux of 71 lumens per watt, whereas in contrast, the best tungsten bulbs produce only 30lumens per watt. No dichroic tungsten filter was used for the measurements. To ensure a constant light intensity over all measurements and sampling dates the light intensity was calibrated against known references as indicated by Graeff [25].

Three plants per plot were used as a subsample of the whole plot for the measurements. Images were taken without removing the leaf from the plant. A leaf area of $4.5 \mathrm{~cm}^{2}$ was scanned at a point about one-quarter of the way from the base to the tip. The leaf to be measured was laid on a black aluminum plate mounted $15-20 \mathrm{~cm}$ away from the optics (1.28/60 mm, LEICA, Germany) of the imager. The imager was oriented vertically and scanned the reflectance through the visible $(380-780 \mathrm{~nm})$ and NIR (750-1300 nm) wavelength ranges at given long-pass filter intervals at a rate of 1 scan per 24 milliseconds. Selected long-pass filters (Maier Photonics, Manchester, VT, USA) were active at wavelengths longer than $380 \mathrm{~nm}(400-2000 \mathrm{~nm}$ transm. avg. 90\%), $490 \mathrm{~nm}$ (500-2000 nm transm. avg. $90 \%), 510 \mathrm{~nm}(520-2000 \mathrm{~nm}$ transm. avg. 90\%), $516 \mathrm{~nm}$ (525-2000 nm transm. avg. 90\%), $540 \mathrm{~nm} \mathrm{(550-2000} \mathrm{nm}$ transm. avg. 90\%), and $600 \mathrm{~nm}$ (610-2000 nm transm. avg. 90\%), respectively. The long-pass filters had the following general specifications: thickness $3 \mathrm{~mm}$, hard-oxide coating surface, quality $80 / 50$ per MIL-O-13830A, coating quality $60 / 40$ per MIL-O-13830A, and temperature limits from -50 to $100^{\circ} \mathrm{C}$.

For each plant, images were taken performed with the above-mentioned long-pass filters in conjunction with an LEICA Daylight Filter IRa E55 to cut all scans at $780 \mathrm{~nm}$ (wavelength ranges indicated with $X_{780} \mathrm{~nm}$ ). A second set of scans was taken without this daylight filter in order to scan in the near-infrared ranges, indicated with $X_{1300} \mathrm{~nm}$.
Digital image data were studied to select feature wavelengths, that is, the wavelengths at which contrasts in spectral responses between major object categories became distinct. Images were analyzed with ADOBE Photoshop 5.0 (file type *.psd, 8-bit) in the $L^{*} a^{*} b^{*}$-color system [24] by splitting the images into $a^{*}$ and $b^{*}$ parameters in different wavelength ranges. In the $L^{*} a^{*} b^{*}$-color system the values $L^{*}, a^{*}$, and $b^{*}$ are plotted using a Cartesian coordinate system. Equal distances in the space approximately represent equal color differences. Value $L^{*}$ represents lightness; value $a^{*}$ represents the red/green axis; and value $b^{*}$ represents the yellow/blue axis. CIELAB is a popular color space for use in measuring reflective and transmissive objects. Color features were defined using spectral responses at these feature wavelengths in the form of $a^{*}$ and $b^{*}$ parameters. Observations of the spectra of the 11 filter classes revealed that, at certain wavelengths, the contrasts between major object categories were maximized. The reflectance calibrations defined by Graeff et al. [22] and Graeff and Claupein [26] were used as starting point to identify possible nitrogen limiting conditions.

\subsection{Color theory}

In the last couple of years, low-cost digital imaging methods have become readily available easing the set-up of calibrations for the detection of different plant stresses. In 1986, the Commission Internationale d'Eclairage (CIE) updated and refined the three-dimensional Lab color system, which displays every color perceived by the human eye [24]. The values represent a precise, objective, and unambiguous measure of color that is independent of imaging capabilities [27]. The technique applied in this study uses characteristics of the CIELAB chromaticity parameters and relates them mathematically to the response of plants due to nitrogen demand. The evaluation of the nitrogen demand is based on the mathematical expression of the difference between CIELAB chromaticity values of a normal fed and a deficient plant. Hence, the determined spectral features used to quantify plant $\mathrm{N}$ demand should not be confused with human perceived colors. Giving an equation of colorimetric alteration directly related to the nutritional status of a plan, could help the final user in the interpretation of the raw data, regardless of the color.

\subsection{Analyses}

After taking the images, the measured plants were harvested and the fresh weight was determined at once. Plant samples were dried at $60^{\circ} \mathrm{C}$ and total dry matter was determined. The scanned leaf was ground and analyzed for total $\mathrm{N}$ concentration according to Dumas [28] by means of a Heraeus macro-N-analyzer (Hanau, Germany).

$\mathrm{N}$ balance was calculated based on nitrogen uptake calculated as the product of the crop biomass (dry weight) and the $\mathrm{N}$ concentrations in plant material at final harvest date, the $\mathrm{N}_{\text {min }}$ left in the soil after harvest and the total input of nitrogen given as fertilizer rate and $\mathrm{N}_{\min }$ in the soil at planting date. 


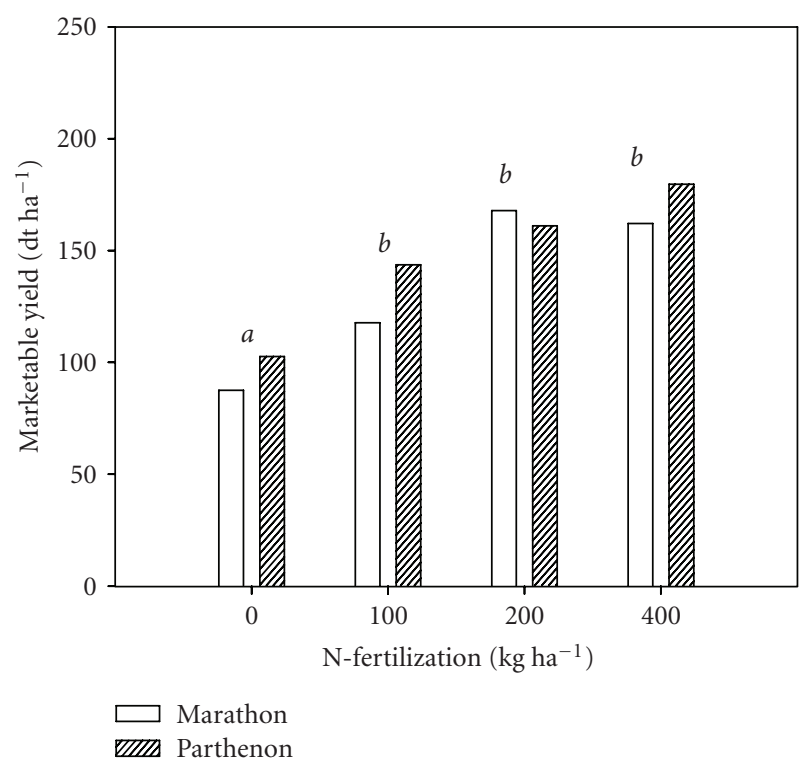

(a)

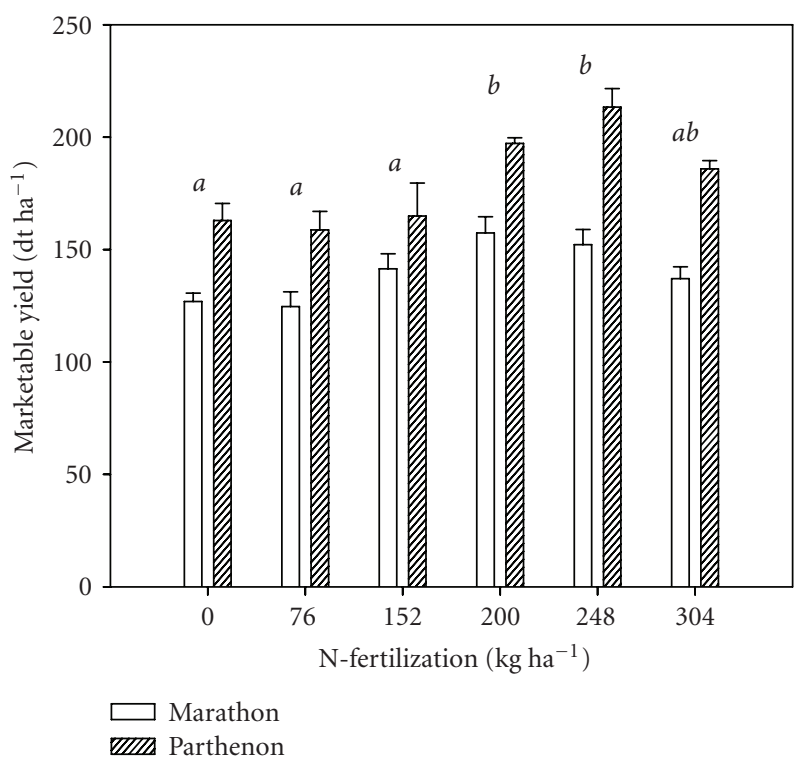

(b)

FIGURE 1: Marketable yield of broccoli cv. Marathon and Parthenon $\left[\mathrm{dt} \mathrm{ha}^{-1}\right]$ for different $\mathrm{N}$ fertilizer levels in the two field trials $($ trial $1=$ $a$, trial $2=b$ ). Significant differences are indicated for fertilizer treatments at the $\alpha=0.05$ probability level.

\subsection{Statistical analysis}

Analysis of variance (ANOVA) was carried out on all crop and reflectance data using the general procedures of the Tukey minimum significant difference (MSD) test at the $5 \%$ significance level of the Statistical Analysis System (SAS) version 6.12. Regression analyses were performed to determine the association among the plant nitrogen concentration and spectral properties of the plants.

\section{RESULTS AND DISCUSSION}

\subsection{Yield}

Climatic conditions in 2006 were favorable for growth of broccoli with additional irrigation. Yield of broccoli cv. Parthenon exceeded yield of cv. Marathon in both trials. Figure 1 provides the results of yield of both cultivars and both field experiments depending on the different $\mathrm{N}$ fertilizer treatments. Yield levels increased with $\mathrm{N}$ application rates. Maximum yield of $215 \mathrm{dt} \mathrm{ha}^{-1}$ was obtained with the treatment of $200 \mathrm{~kg} \mathrm{~N} \mathrm{ha}^{-1}$ of $\mathrm{N}$, while no further yield increases were obtained at higher $\mathrm{N}$ levels $\left(400 \mathrm{~kg} \mathrm{ha}^{-1}\right)$. In other studies, the maximum reported yields ranged from 100 to $150 \mathrm{dt} \mathrm{ha}^{-1}[29,30]$. These authors reported an optimum $\mathrm{N}$ level of $250 \mathrm{~kg} \mathrm{ha}^{-1}$ to attain a yield of $95 \mathrm{dt} \mathrm{ha}^{-1}$. In our study, the optimum $\mathrm{N}$ rate was lower, but resulted in higher yields, probably due to different growing conditions. Floret diameter and floret weight of both varieties were most responsive to $\mathrm{N}$ rates across the range of treatments. No quality parameter maxima were predicted within the range of treatments, except for floret weight.

Visual inspection of the different $\mathrm{N}$ treatments in the plots provided an estimate of the fresh market quality variability within each plot and within each fertilizer treatment. Visual inspection confirmed variability reduction in market quality characteristics such as light green to yellow appearance and floret and plant size in plots treated with nitrogen rates $>200 \mathrm{~kg} \mathrm{ha}^{-1}$. The 200 and $400 \mathrm{~kg} \mathrm{~N} \mathrm{ha}^{-1}$ plots were more consistent in their dark green appearance as well as in plant and floret size throughout the plots than the 0 and $100 \mathrm{~kg} \mathrm{~N} \mathrm{ha}^{-1}$ plots. However, the quality parameters discoloration and hollow stem were not different across the treatments.

Except at the lowest $\mathrm{N}$ rate, both varieties showed excellent yield and quality across the range of $\mathrm{N}$ treatments. Predicted maximum yields and quality occurred at $\mathrm{N}$ rates $>200 \mathrm{~kg} \mathrm{ha}^{-1}$ (Figure 1) indicating that under the local field conditions the optimum fertilizer amount for row crop broccoli production consists of an adequate application of $\mathrm{N}>200 \mathrm{~kg} \mathrm{ha}^{-1}$ for both cultivars. These $\mathrm{N}$ rates are lower than currently recommended rates of $>300 \mathrm{~kg} \mathrm{ha}^{-1}$ [30, 31]. However, Stivers et al. [32] reported that broccoli growers may apply as much as $400 \mathrm{~kg} \mathrm{~N} \mathrm{ha}^{-1}$ to achieve high yields. Other researchers have noted a positive broccoli yield response to $\mathrm{N}$ rates as high as $330 \mathrm{~kg} \mathrm{ha}^{-1}$ in California [33] and $>500 \mathrm{~kg} \mathrm{ha}^{-1}$ in British Columbia [34]. The N rates associated with maximum yield in our experiments are likely lower than would be needed in a normal production situation, as soil mineralization was high due to clover-grass as previous crop.

\subsection{Image analysis-calibrations for $\mathbf{N}$ demand}

Figures $2(\mathrm{a})$ and $2(\mathrm{~b})$ indicate that the $b^{*}$ parameter of both varieties increased significantly in the wavelength range $516_{780} \mathrm{~nm}$ with decreasing $\mathrm{N}$ fertilization rates and thus decreasing $\mathrm{N}$ rates in leaf dry matter. Reflectance spectra 


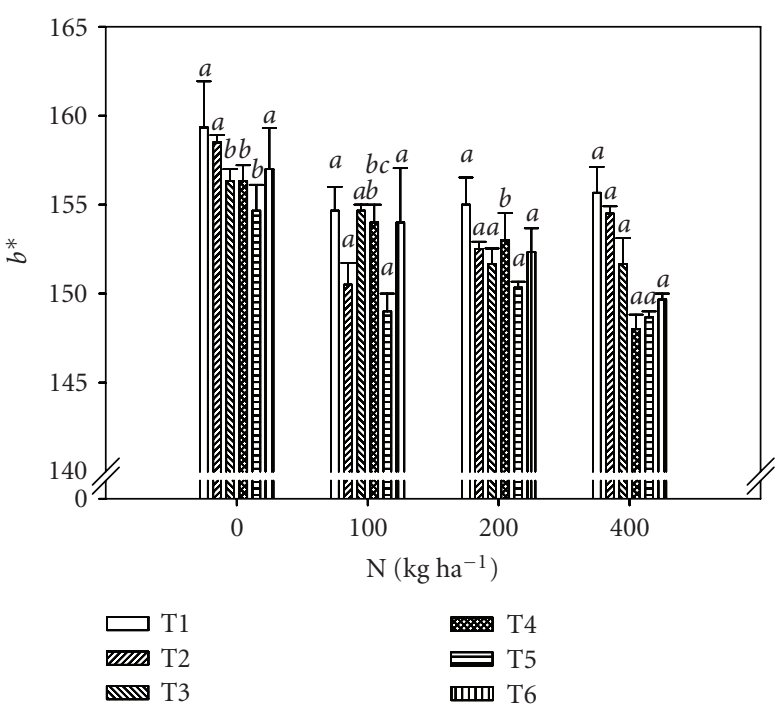

(a)

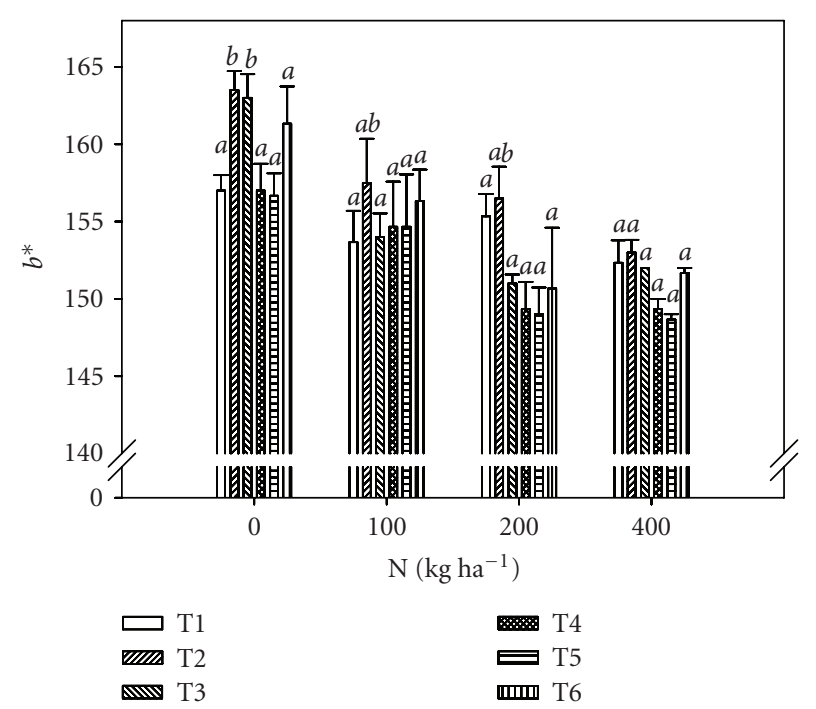

(b)

FIgure 2: Reflectance changes of broccoli cv. Parthenon (a) and Marathon (b) for different N fertilizer levels over a period of 6 weeks (T1T6) indicated by the $b^{*}$ parameter in the wavelength range $516_{780} \mathrm{~nm}$. Significant differences $(\alpha=0.05)$ are indicated between $\mathrm{N}$ rates at the different measurement dates $(\mathrm{T} 1=$ after planting $-\mathrm{T} 6=$ harvest $)$.

of young unfolded leaves of the treatment $0 \mathrm{~N} \mathrm{~kg} \mathrm{ha}^{-1}$ were significantly different from the reflectance spectra of $200 \mathrm{~N} \mathrm{~kg} \mathrm{ha}^{-1}$ and $400 \mathrm{~kg} \mathrm{ha}^{-1}$ leaves starting from T2 for the variety Marathon and T3 for the variety Parthenon. Significant changes in determined color features expressed by $a^{*}$ and $b^{*}$ parameters revealed that certain wavelengths especially in the visible spectra maximized the contrasts between $a^{*}$ and $b^{*}$ parameters and thus between $\mathrm{N}$ levels. Over all tested wavelength ranges, the wavelength ranges $510_{780} \mathrm{~nm}, 516_{780} \mathrm{~nm}$, and $380_{780} \mathrm{~nm}$ seemed to be well suited for the identification of broccoli N status. Further, the results also indicated that due to genetic variation among tested cultivars and thus different development and $\mathrm{N}$ uptake rates, the spectral signatures differed between the varieties expressed as absolute values and the timing the $\mathrm{N}$ concentration decreased below a certain critical level. Especially cv. Marathon seems to develop earlier and faster than $\mathrm{cv}$. Parthenon, necessitating an earlier $\mathrm{N}$ fertilizer application than the variety Parthenon to sustain leaf development (Figures 2(a), 2(b)). Further, using $a^{*}$ and $b^{*}$ parameters individually lead to better results than using a combination of both parameters.

The constancy of modified reflectance in the visible region as a response to nitrogen level was evident among the different $\mathrm{N}$ fertilizer treatments. It was obvious that a successful identification and quantification of nitrogen status was possible. The wavelength band in the green range $(500-600 \mathrm{~nm})$ seemed to be the most important wavelength band for the determination of nitrogen status. Reflectance in the visible region of the spectra is mainly influenced by pigmental changes. Gates et al. [35] found that the characteristics of plant reflectance are functions of leaf geometry, morphology, physiology, and biochemistry. They are influenced by soil and climatic conditions [35] and nutrient status [36]. Excess or deficiency of an essential element may cause visible abnormalities in pigmentation, size, and shape of leaves [19]. We suppose that $\mathrm{N}$ status affected leaf pigments (mainly chlorophyll) of the measured leaves during the growing process and led to the determined reflectance changes.

To relate leaf reflectance response to $\mathrm{N}$ demand, the parameter $b^{*}$ was correlated with the chemically determined $\mathrm{N}$ concentration in leaf dry matter. The relationship was best described by a linear model. Equations (1) represent the mathematical relationship used to quantify plant $\mathrm{N}$ through CIELAB chromaticity parameters for each tested cultivar:

$$
\begin{aligned}
& F\left(x_{\text {Parthenon }}\right)=164.31-2.05 x, \\
& F\left(x_{\text {Marathon }}\right)=167.48-2.79 x .
\end{aligned}
$$

Plants were analyzed at several growth stages to develop sufficiency levels for $\mathrm{N}$. Leaf $\mathrm{N}$ concentration varied depending on the fertilizer treatment and growth stage between $2 \%$ $\mathrm{N}$ and $8 \% \mathrm{~N}$. Total $\mathrm{N}$ ranged from 5.5 to $8 \%$ from the early growth stages until first bud, but was reduced to 4$6 \%$ at floret formation and to $2-5 \%$ during the preharvest stage. Lower sufficiency values at heading have been reported by others $[37,38]$. Nitrogen uptake by broccoli typically ranges from 150 to $280 \mathrm{~kg} \mathrm{ha}^{-1}[30,32]$. Rates of $\mathrm{N}$ used by broccoli growers may be as high as $400 \mathrm{~kg} \mathrm{ha}^{-1}$ [32] whereof broccoli florets typically account for 10 to $45 \%$ of the $\mathrm{N}$ taken-up. Broccoli is a rapidly-growing crop that takes up little $\mathrm{N}$ in its first $40 \mathrm{~d}$ of growth, and $90 \%$ or more of its total $\mathrm{N}$ accumulation may occur during the final 30 to $50 \mathrm{~d}$ preceding harvest [30]. Broccoli plants are highly responsive to $\mathrm{N}$ fertilizer inputs, and excessive $\mathrm{N}$ inputs can result in decreased quality like hollow stem [32]. According to Bergmann [39] $\mathrm{N} \geq 3.0 \%$ was defined as adequate nutrient concentration in the plant dry matter around heading. In 


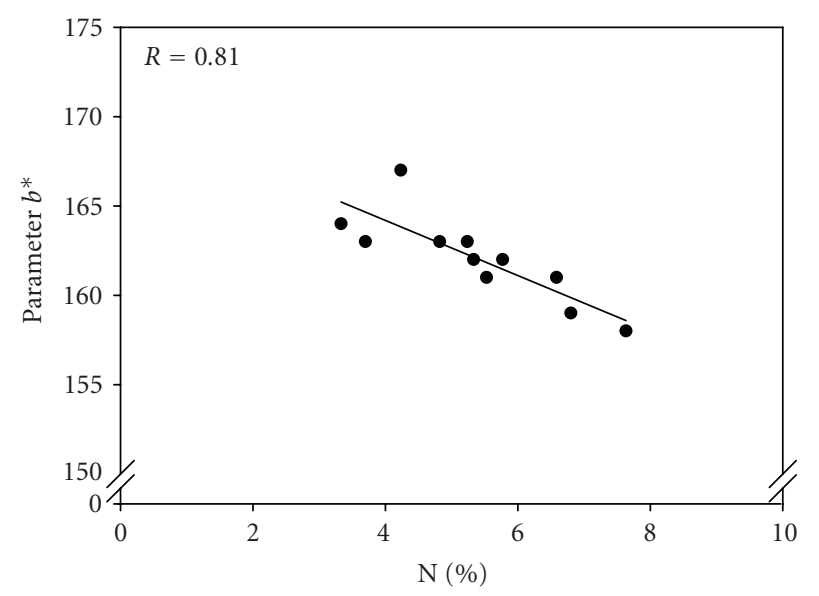

(a)

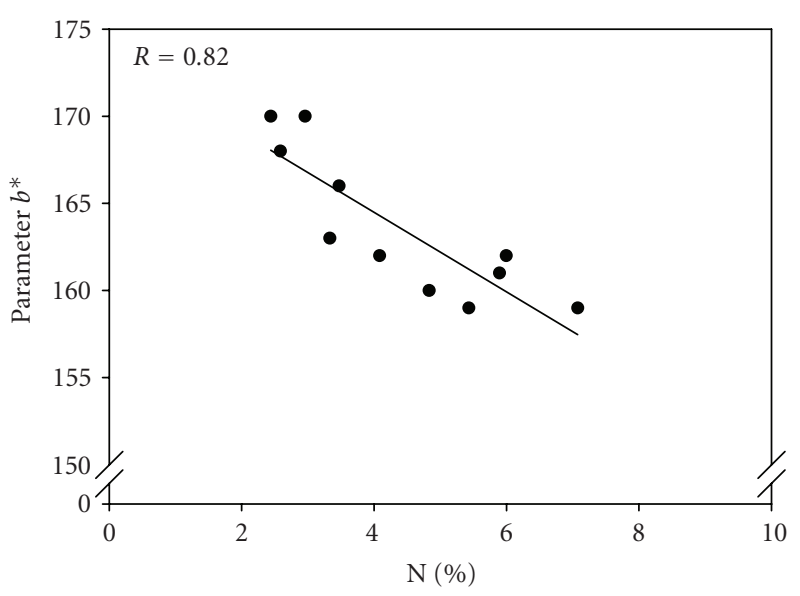

(b)

FIgURE 3: Linear regression between the $\mathrm{N}$ concentration in leaf dry matter [\%] and the parameter $b^{*}$ in the wavelength range $516_{780} \mathrm{~nm}$ for the broccoli cultivars Parthenon (a) and Marathon (b). A correlation coefficient of $R=0.81$ was obtained for Parthenon and $R=0.82$ was obtained for Marathon over the tested nitrogen levels.

consequence, the amount of $\mathrm{N}$ applied in the $200 \mathrm{~kg} \mathrm{ha}^{-1}$ treatment was considered as nonlimiting during the whole time of the experiment, because leaf $\mathrm{N}$ was higher than $3.0 \%$. Therefore, reflectance values of the $200 \mathrm{~kg} \mathrm{~N} \mathrm{ha}^{-1}$ treatment were taken as a reference for an adequately $\mathrm{N}$ fed broccoli plant in a high input production system and as a basis to calculate necessary $\mathrm{N}$ fertilizer amounts around floret formation.

Over all treatments and both cultivars, the parameter $b^{*}$ increased in the visible spectrum, when $\mathrm{N}$ was deficient. The relation of reflectance parameter $b^{*}$ and leaf $\mathrm{N}$ concentration was best described by a linear model in the visible wavelength ranges (Figures 3(a), 3(b)). Some of the calibration curves using particular wavelength ranges especially in the infrared predicted leaf $\mathrm{N}$ concentration poorly $(R=0.1)$ (results not shown). The highest correlation coefficients were obtained in the wavelength ranges $510_{780} \mathrm{~nm}(R=0.85$ for "Marathon"; $R=0.83$ for "Parthenon") (Figures 3(a), 3(b)), $516_{780} \mathrm{~nm}$ $(R=0.72)$, and $380_{780} \mathrm{~nm}(R=0.71)$ (results not shown). The derived equations $f$ (Parthenon 516 $\left.6_{780} \mathrm{~nm}\right)=164.310-$ $2.059^{*} x$ and $f$ (Marathon 516 $\left.780 \mathrm{~nm}\right)=167.486-\left(2.793^{*} x\right)$ were used to calculate necessary $\mathrm{N}$ fertilizer amounts for the second $\mathrm{N}$ application rate in the validation field trial.

Knowledge of crop nitrogen demand is essential in predicting crop needs and, therefore, in developing reliable fertilizer recommendations for growers. Such recommendations are critical, for both economic and environmental reasons [40]. The $\mathrm{N}$ demand of a crop is defined as the $\mathrm{N}$ uptake over a set period, which allows the maximum dry matter growth rate under a given set of environmental conditions [41]. The conventional fertilization method of vegetables in the field provides high $\mathrm{N}$ amounts to ensure a constant $\mathrm{N}$ supply to the plant throughout the crop cycle. The conventional optimal $\mathrm{N}$ rate is selected as the one allowing just maximal yield at harvest. Since $\mathrm{N}$ demand is variable over time, each plant growth stage and also each variety may have a specific $\mathrm{N}$ rate at which its growth rate

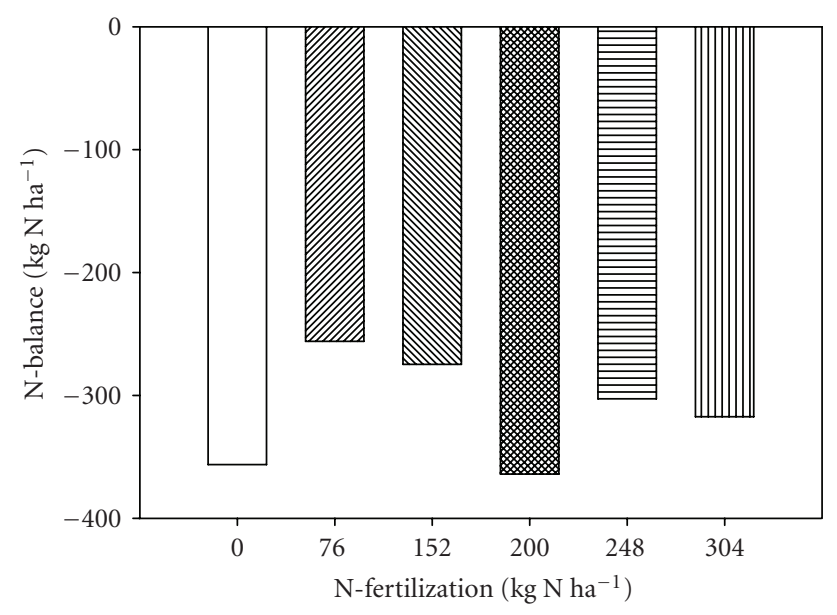

FIgURE 4: N-balance $\left[\mathrm{kg} \mathrm{N} \mathrm{ha}{ }^{-1}\right]$ of the validation trial for the different fertilizer treatments (mean over both varieties).

is the fastest. Consequently, the conventional optimal $\mathrm{N}$ rates may either underestimate the instantaneous $\mathrm{N}$ demand $(\mathrm{N}$ uptake rate allowing just maximum growth), at the stages where it is the highest, or overestimate it, at the stages where it is the lowest. This will lead either to yield and quality reduction, or to high $\mathrm{N}$ amounts left in the soil after harvest. Especially in this context, the fast and easy determination of broccoli $\mathrm{N}$ demand in order to properly estimate needed $\mathrm{N}$ fertilizer amounts by the use of digital image analysis gains in importance.

\subsection{Validation of calculated $\mathbf{N}$ amounts}

Decisions needed to give appropriate advice on the amounts and timing of $\mathrm{N}$ to be applied to crops depend on a complex interaction of processes which can be represented in mathematical models. Determined regressions between spectral 
parameters and chemically determined nitrogen amounts were used to calculate the necessary $\mathrm{N}$ fertilizer amounts for the second $\mathrm{N}$ application rate in field trial 2 around floret formation. Digital images were taken around floret formation and evaluated for changes in the $b^{*}$ parameter. Determined $b^{*}$ parameters replaced the variables in the equations of the calibration process and let to final calculated $\mathrm{N}$ fertilizer amounts. Determined $\mathrm{N}$ amounts were applied directly in the field.

The comparison of determined $\mathrm{N}$ rates by digital image analysis with the standard application rate of farmers indicated that determined $\mathrm{N}$ rates based on digital image analysis were $100 \mathrm{~kg} \mathrm{ha}^{-1}$ lower than the standard application rate, while no significant changes were observed between yield and quality levels of these treatments (Figure 1). Further, the $\mathrm{N}$ balance showed a high and efficient $\mathrm{N}$ uptake of broccoli plants of up to $365 \mathrm{~kg} \mathrm{ha}^{-1}$, indicating a high $\mathrm{N}$ utilization rate without leaving high $\mathrm{N}$ amounts in the soil after harvest (Figure 4). Other researchers have also reported broccoli aboveground $\mathrm{N}$ uptake well in excess of $300 \mathrm{~kg} \mathrm{ha}^{-1}$ $[34,42]$. However, the pattern of $\mathrm{N}$ uptake, with low $\mathrm{N}$ uptake early in the season followed by a period of rapidly increasing uptake, illustrates the management challenge posed by broccoli production. An adequate supply of $\mathrm{N}$ is required all season. Preplant or early-season applications of $\mathrm{N}$ may be inefficiently used because of low plant $\mathrm{N}$ demand. $\mathrm{N}$ application around floret formation was fully used by the broccoli plants in our experiment, wherefore a split of nitrogen fertilizer amounts is highly recommended in broccoli production. Estimating the $\mathrm{N}$ demand of broccoli plants around floret formation by fast and easy spectral measurements will help to improve yield and quality and contribute to the reduction of $\mathrm{N}$ left in the soil after harvest in intensive horticultural cropping systems. Overall, the results suggest that digital image analysis and reflectance data can be a nondestructive, rapid, cost-effective, and reproducible technique to determine $\mathrm{N}$ demand in broccoli with repeatable accuracy and precision.

Overall, this paper presents a new and simple technique to derive quantitative estimates of broccoli nitrogen status using CIELAB chromaticity parameters as information source from digital images. This technique is based on the association of changing leaf color due to nitrogen status of broccoli plants. Nitrogen status is reflected by with a representative wavelength region on a two-dimensional colour space, and applies to cases of single leaf measurements under controlled light conditions. The efficacy of the method is demonstrated using sets of samples obtained from both field and laboratory studies. It is shown that application of the proposed approach results in a highly linear relationship between chromaticity parameters and nitrogen status of broccoli plants. The method outlined here allows for a substantial improvement in the speed of sample evaluation to estimate broccoli $\mathrm{N}$ status both in the field and in the laboratory. The technique of the $L^{*}, a^{*}$, and $b^{*}$ values defined for different $\mathrm{N}$ concentrations in leaf dry matter provided a range of chromaticity parameters that can be successfully utilized in digital image screening processing.

\section{CONCLUSION}

The results of this study represent a first step of using CIELAB chromaticity parameters to evaluate the nitrogen status of broccoli plants and to derive $\mathrm{N}$ fertilizer recommendations out of determined spectral values. The approach using leaf reflectance parameters derived from high-resolution digital images indicated to be an effective technique for estimating $\mathrm{N}$ fertilizer amounts for broccoli around floret formation in specific wavelength ranges. The spectral properties showed high correlations with chemically determined $\mathrm{N}$ concentrations and required less time and labor than current standard methods. Reflectance measurements appear to be sufficiently discriminating between different nitrogen fertilizations to permit practical use and to help growers make better-informed management decisions about nitrogen and fertilizer applications during the season. However, before such tools can be incorporated into the nitrogen management strategy of horticultural crops, threshold values first have to be established as a criterion for crop nitrogen supplementation. Furthermore, differences in seasonal development of different cultivars might necessitate multiple time frames for an in-season fertilization treatment. Evaluation will continue.

\section{REFERENCES}

[1] C. W. Wood, D. W. Reeves, R. R. Duffield, and K. L. Edminsten, "Field chlorophyll measurements for evaluation of corn nitrogen status," Journal of Plant Nutrition, vol. 15, no. 4, pp. 487-500, 1992.

[2] J. E. Erickson, M. D. Keziah, L. A. Nelson, and C. T. Young, "Variation of color of oil cooked Virginia type peanuts," Proceedings of the American Peanut Research and Education Society, vol. 20, p. 45, 1988.

[3] L. T. Bennett, T. S. Judd, and M. A. Adams, "Close-range vertical photography for measuring cover changes in perennial grasslands," Journal of Range Management, vol. 53, no. 6, pp. 634-641, 2000.

[4] M. Louhaichi, M. M. Borman, and D. E. Johnson, "Spatially located platform and aerial photography for documentation of grazing impacts on wheat," Geocarto International, vol. 16, no. 1, pp. 65-70, 2001.

[5] M. D. Richardson, D. E. Karcher, and L. C. Purcell, "Quantifying turf grass cover using digital image analysis," Crop Science, vol. 41, no. 6, pp. 1884-1888, 2001.

[6] D. T. Booth, S. E. Cox, C. Fifield, M. Phillips, and N. Willlamson, "Image analysis compared with other methods for measuring ground cover," Arid Land Research and Management, vol. 19, no. 2, pp. 91-100, 2005.

[7] R. T. Sherwood, C. C. Berg, M. R. Hoover, and K. E. Zeiders, "Illusions in visual assessment of Stagonospora leaf spot of orchardgrass," Phytopathology, vol. 73, no. 2, pp. 173-177, 1983.

[8] F. J. Adamsen, P. J. Pinter Jr., E. M. Barnes, et al., "Measuring wheat senescence with a digital camera," Crop Science, vol. 39, no. 3, pp. 719-724, 1999.

[9] K. Steddom, M. McMullen, B. Schatz, and C. M. Rush, "Assessing foliar disease of wheat image analysis," in Proceedings of the Summer Crops Field Day Sponsored by the Cooperative Research, Education \& Extension Team (CREET '04), pp. 3238, Bushland, Tex, USA, 2004. 
[10] M. Flowers, R. Weisz, and R. Heiniger, "Remote sensing of winter wheat tiller density for early nitrogen application decisions," Agronomy Journal, vol. 93, no. 4, pp. 783-789, 2001.

[11] W. E. Wildman, "Detection and management of soil, irrigation, and drainage problems," in Remote Sensing for Resource Management, C. J. Johannsen and J. L. Sanders, Eds., pp. 387-401, Soil Conservation Society of America, Ankeny, Iowa, USA, 1982.

[12] T. M. Blackmer, J. S. Schepers, G. E. Varvel, and G. E. Meyer, "Analysis of aerial photography for nitrogen stress within corn fields," Agronomy Journal, vol. 88, no. 5, pp. 729-733, 1996.

[13] T. M. Blackmer and J. S. Schepers, "Aerial photography to detect nitrogen stress in corn," Journal of Plant Physiology, vol. 148, no. 3-4, pp. 440-444, 1996.

[14] H.-E. Nilsson and L. Johnsson, "Hand-held radiometry of barley infected by barley strip disease in a field experiment," Journal of Plant Diseases and Protection, vol. 103, pp. 517-526, 1996.

[15] W. E. Riedell and T. M. Blackmer, "Leaf reflectance spectra of cereal aphid-damaged wheat," Crop Science, vol. 39, no. 6, pp. 1835-1840, 1999.

[16] J. Lowenberg-DeBoer, "Precision farming or convenience agriculture," in Proceedings of the 11th Australian Agronomy Conference, Geelong, Australia, February 2003.

[17] P. M. R. Dampney and G. Goodlass, "Quantifying the variability of soil and plant nitrogen dynamics within arable fields growing combinable crops," in Proceedings of the 1st European Conference on Precision Agriculture, J. V. Stafford, Ed., vol. 1, pp. 219-226, BIOS Scientific, Warwick, UK, September 1997.

[18] R. L. Hoskinson, J. R. Hess, and R. S. Alessi, "Temporal changes in the spatial variability of soil nutrients," in Proceedings of the 2nd European Conference on Precision Agriculture, J. V. Stafford, Ed., pp. 61-70, Sheffield Academic Press, Odense, Denmark, July 1999.

[19] A. H. Al-Abbas, R. Barr, J. D. Hall, F. L. Crane, and M. F. Baumgardner, "Spectra of normal and nutrient-deficient maize leaves," Agronomy Journal, vol. 66, no. 1, pp. 16-20, 1974.

[20] M. L. Adams, W. A. Norvell, W. D. Philpot, and J. H. Peverly, "Toward the discrimination of manganese, zinc, copper, and iron deficiency in 'Bragg' soybean using spectral detection methods," Agronomy Journal, vol. 92, no. 2, pp. 268-274, 2000.

[21] A. Masoni, L. Ercoli, and M. Mariotti, "Spectral properties of leaves deficient in iron, sulfur, magnesium, and manganese," Agronomy Journal, vol. 88, no. 6, pp. 937-943, 1996.

[22] S. Graeff, D. Steffens, and S. Schubert, "Use of reflectance measurements for the early detection of $\mathrm{N}, \mathrm{P}, \mathrm{Mg}$, and $\mathrm{Fe}$ deficiencies in Zea mays L." Journal of Plant Nutrition and Soil Science, vol. 164, no. 4, pp. 445-450, 2001.

[23] J. E. Colwell, "Vegetation canopy reflectance," Remote Sensing of Environment, vol. 3, no. 3, pp. 175-183, 1974.

[24] CIE, Colorimetry, Central Bureau of the Commission Internationale de L'Eclairage, Vienna, Austria, 2nd edition, 1986.

[25] S. Graeff, Früherkennung von Ernährungsstörungen bei Zea mays L. mittels Blatt-Reflexionsmessungen, Ph.D. thesis, University of Gießen, Gießen, Germany, 2000.

[26] S. Graeff and W. Claupein, "Quantifying nitrogen status of corn (Zea mays L.) in the field by reflectance measurements," European Journal of Agronomy, vol. 19, no. 4, pp. 611-618, 2003.

[27] G. Wyszeckei and W. S. Stiles, Color Science: Concepts and Methods, John Wiley \& Sons, New York, NY, USA, 1982.
[28] A. Dumas, Stickstoffbestimmung nach Dumas. Die Praxis des org. Chemikers. (N-determination according to Dumas), Schrag, Nürnberg, Germany, 41th edition, 1962.

[29] L. Rincón, J. Sáez, J. A. Perez, and M. D. Gomez, Crecimiento y Absorción de Nutrients de Brócoli. Memorias del Primer Congreso Ibérico de Fertirrigación, Sociedad Española de Ciencias Hortícolas, Madrid, Spain, 1997.

[30] T. A. Doerge and T. L. Thompson, "Optimizing water and fluid nitrogen inputs for subsurface trickle irrigated broccoli and cauliflower," in Proceedings of the Fluid Forum, pp. 104-113, Fluid Fertilizer Foundation, Scottsdale, Ariz, USA, 1997.

[31] C. Scharpf, Stickstoffdüngung im Gemüsebau, AID-Heft, Bonn, Germany, 1991.

[32] L. J. Stivers, L. E. Jackson, and G. S. Pettygrove, Use of Nitrogen by Lettuce, Celery, Broccoli, and Cauliflower: A Literature Review, California Department of Food and Agriculture, Sacramento, Calif, USA, 1993.

[33] R. B. Beverly, W. M. Jarrell, and J. Letey Jr., "A nitrogen and water response surface for sprinkler-irrigated broccoli," Agronomy Journal, vol. 78, no. 1, pp. 91-94, 1986.

[34] B. J. Zebarth, P. A. Bowen, and P. M. Toivonen, "Influence of nitrogen-fertilization on broccoli yield, nitrogen accumulation and apparent fertilizer-nitrogen recovery," Canadian Journal of Plant Science, vol. 75, no. 3, pp. 717-725, 1995.

[35] D. M. Gates, H. J. Keegan, J. C. Schleter, and V. R. Weidner, "Spectral properties of plants," Applied Optics, vol. 4, no. 1, pp. 11-20, 1965.

[36] D. M. Gates, "Physical and physiological properties of plants," in Remote Sensing with Special Reference to Agriculture and Forestry, pp. 224-252, National Academy of Sciences, Washington, DC, USA, 1970.

[37] D. J. Reuter and J. B. Robinson, Plant Analysis: An Interpretation Manual, Inkata Press, Melbourne, Australia, 1986.

[38] J. B. Jones Jr., B. Wolf, and H. A. Mills, Plant Analysis Handbook: A Practical Sampling, Micro Macro, Athens, Ga, USA, 1991.

[39] W. Bergmann, Ernährungsstörungen bei Kulturpflanzen, Gustav Fischer, Jena, Germany, 1993.

[40] T. M. Addiscot, A. P. Whitmore, and D. S. Powlson, Farming, Fertilizers and the Nitrate Problem, CAB International, Wallingford, UK, 1991.

[41] D. J. C. Grindlay, “Towards an explanation of crop nitrogen demand based on the optimization of leaf nitrogen per unit leaf area," The Journal of Agricultural Science, vol. 128, no. 4, pp. 377-396, 1997.

[42] V. Magnifico, V. Lattanzio, and G. Sarli, "Growth and nutrient removal by broccoli," Journal of the American Society for Horticultural Science, vol. 104, no. 2, pp. 201-203, 1979. 

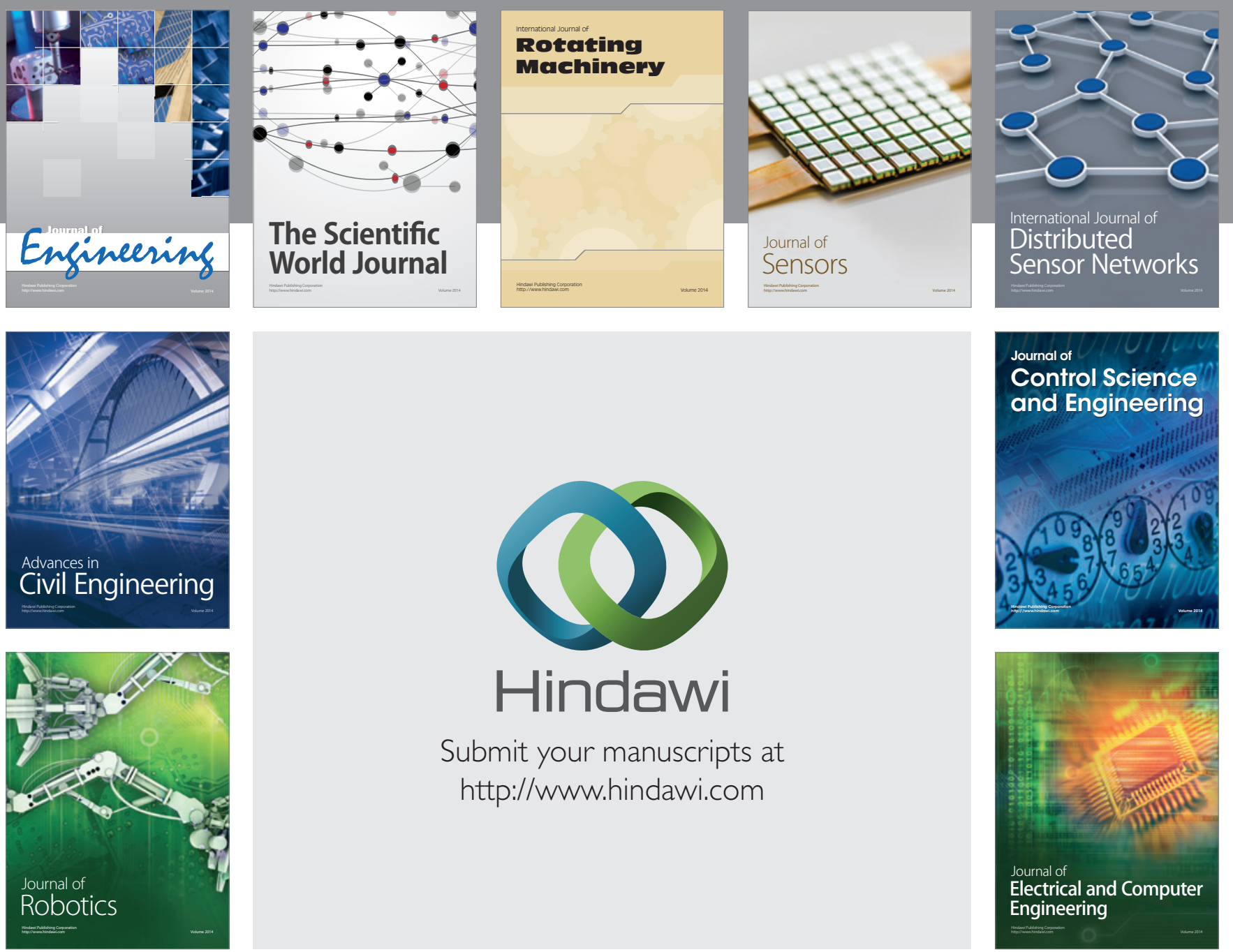

Submit your manuscripts at

http://www.hindawi.com
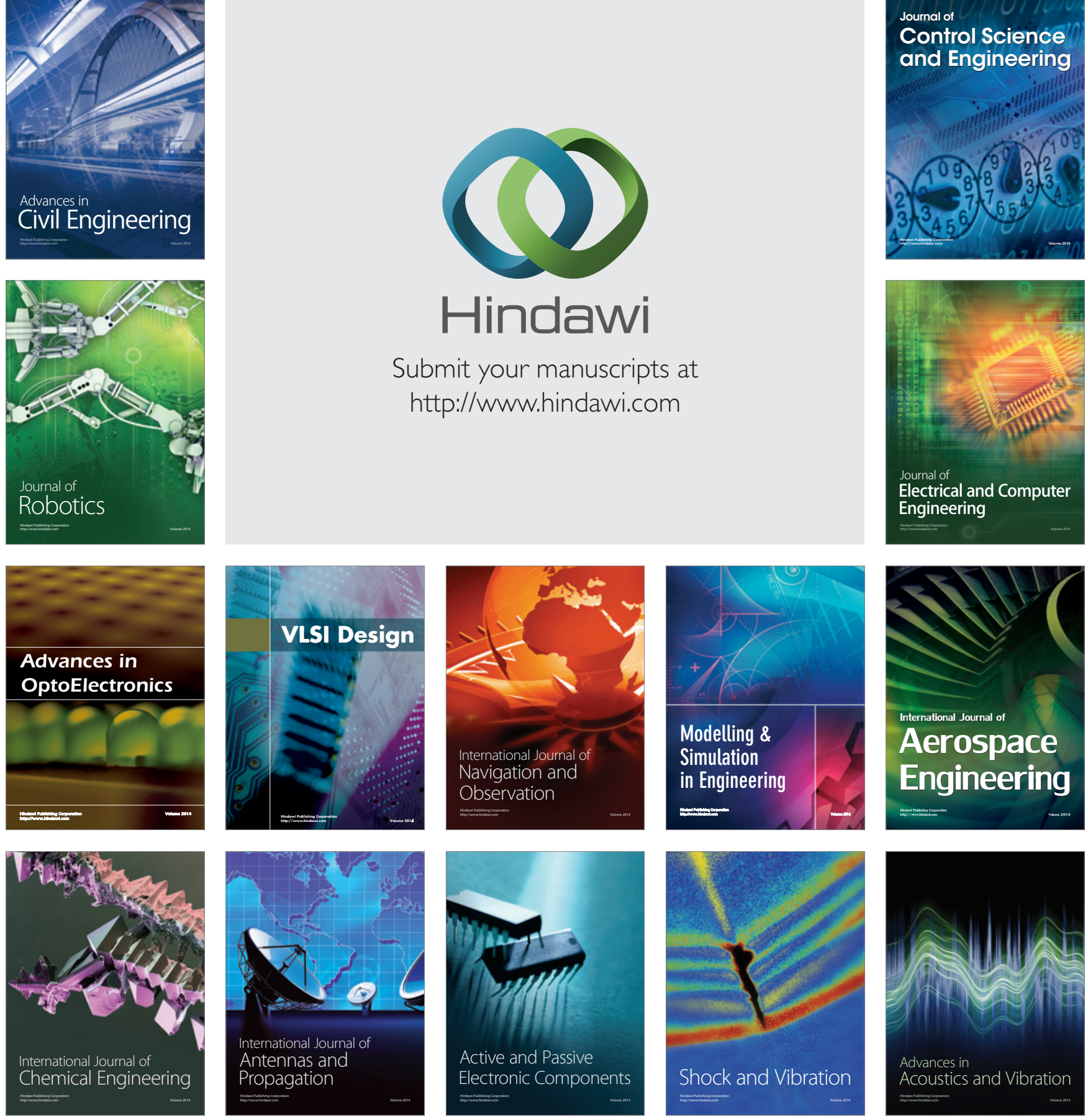